\title{
Tradition and modernity on fundamentals and diversities of Mediterranean architecture
}

\author{
Hugo Fernandes* ${ }^{*}$
}

\begin{abstract}
Firstly, this article focuses on the origins of modern architecture in addition to the simple binomial academism/modernism that sometimes gives little clarification about the aesthetic, formal or typological options of southern European countries. By widening the spectrum of cultural, mythical and ideological influences at the beginning of the 20th century, other insights are possible, not only with regard to the modern period, but also in the understanding of some paths of Mediterranean contemporary production. In short, this article aims to raise two main questions and how can they be related: 1) Does the identity of Mediterranean architecture come from common fundamentals or from a richness of contrasts and diversities? 2) Can these fundamentals and diversities become "operative" in architectural/urban design? And how do they respond to the globalization phenomena and the possibility of real sustainable achievements?
\end{abstract}

\section{Part One}

One could say that Mediterranean space and climate was previously shaped by light. The inner qualities and regional aspects of its medium to warm temperatures and dry weather have, by itself, shaped the landscape. Settlements, as a creation of Man, were bred into these meridional conditions and grew trough adaptation. Natural phenomena shaped traditions which, on their own, have shaped architecture of what is mostly known as the "rational south". So, could this be consequence of the vernacular related to the natural human need of understanding space both as pragmatic and symbolic phenomena? Is the need of spearing local materials and specific building techniques - some of them going back to Antiquity - enough to understand regionalism phenomena and architectural identity?

Erwin Panovsky statted, in 1933, that one of the essential characteristics of the European spirit would be the way it destroys things and then reinstates them on new bases, breaking with tradition only to return to it from a completely new point of view "(...) and this is what produces rebirths, in

* (Corresponding author) Assist. Prof. Dr., Universidade Lusófona, Portugal, \ hugo.nazareth@sapo.pt 
the true sense of the term. So, it is worth saying that what can be called the problem of rebirth phenomena is one of the central problems in the history of European culture" (Tafuri, 1988).

As a result of the cultural crises that has lasted since the 19th century, this is how the civilizational panorama of the European revolution of the 20th century is presented: the period of relative peace and tranquility at the end of the 19th century would prove to be ephemeral, in the environment of restlessness guided by the latent expansionist ambitions of the old European powers, forged in the mythical imaginary of nationalisms with romantic roots, in constant mutation until the Second World War. Although the positive ideas of the Machine Age opened the door to some ruptures, some fundamental aspects of romantic culture would endure in the nationalist and nostalgic myths of the new century, such as cultural values of identity and uniqueness, in parallel with the progressive values of modernity.

These phenomena of change would result in several dichotomies of an ideological, economic, social and artistic nature, between the individual and the collective, the subjective and the objective, artistic production and industrial standardization, under the background of the debates between Art and Technique (Francastel, 1963), which have echoed since Ruskin and Viollet-le-Duc to Muthesius and Van de Velde, inevitably extending the search for an expression between art and society, under the binomial culture/civilization.

But, if in this context of ruptures, numerous aesthetic tendencies arose in reaction to the artistic context "fin-de-siècle", revealing Cubism and the Fauvist and Expressionist paths as revolutionary manifestations of the entrance of the 20th century, it is not to forget that the roots of these movements came from the same trunk common to impressionism and symbolism, whose expression comes from the exploration of the senses and the subconscious (Frampton, 1997).

World War I drastically changed the face of Europe, forcing it to a violent awakening of consciences that were asleep due to centuries of cultural status quo. With the winds of change, the paradigm of modernity was established, forcing a re-alignment of the values, qualities and contents of Western society, with the city and architecture no longer responding to the social, functional and technical needs of the new style of life.

The rupture proposed by the Modern Movement expressed the search for new values, seeks universality and internationalization, but that it was a minority, just like the movement that generated it. Paradoxically, on one hand, the Modern Movement refuted the icons of the monumentality of the past, but, conversely, it reinvented itself in the myths of progress, through factories, skyscrapers and industrial silos, true icons of the modern Zeitgeist and the mythification of the Machine Age, celebrated by Mies van der Rohe in his proposal for the competition of Friedrichstrasse contest (Frampton, 1997) and culminating in Siegfried Giedion «Nine Points on Monumentality» in 1943 (Giedion, 2003).

However, if this, to a certain extent, almost vital effort to internationalize a civilizational discourse around the idea of a "new era" prevailed, the truth is that the old cultural values would not only remain but would regenerate in the period between wars, under the term that HenryRussell Hitchcock came to designate, in 1929, of "New Tradition», and that appeared in simultaneously with the Modern Movement (Frampton, 1997).

It should be remembered that the "New Tradition" has its classic roots in the Noucentisme theorized by Eugénio d'Ors, an artistic-literary movement of the beginning of the 20th century, disseminated in Italy and Catalonia as Novocento, which intended, under this name, to express their particular characteristics within a common current (Galvão, 2003). In this way, there is a reaction to the standardization of architecture conveyed by strictly mechanistic theses, witnessing, in some European countries from the mid-twenties, a repositioning of classic principles, in terms of composition and project methodology. 
In this convergence of new forms the eclecticism of ideas reigns, in the midst of which, however, the more radical proposals of Le Corbusier's purism appear, less well received than the first ones. Simultaneously, as a repository of decorative principles based on the mutability of fashion, the "Art Deco" style, from the 1920s, seems to have been an important agent of the 19th century culture, as an expression of its time, in the constancy of a stylizing virtue, and his attempt at a somewhat paradoxical synthesis between the mainstream and the most marginal discourses.

Another less visible but no less important aspect of the thinking of the 20th century is its construction of modernity that rests on the deep structures of philosophical ideas - and ideals - that somehow contributed to the mythification of the discourses of that same modernity. The idea of transcendence and universality of modern architecture was also based sometimes, in some principles of Platonic idealism, reinforcing its "timelessness". The protagonists of the modern "adventure" enlivened this idealism, although from different references and scales, but all of them sharing the same idea of "regeneration" of Humanity in search of some "universal order". These references were constituted as models through abstraction - or not. In this way, it is assumed that Platonism, like Pythagoreanism, have been - like in other times - silent references by which the immutability of universal mathematical/geometric laws is expressed (Argan, 1997).

Platonic archetypes were present in Viennese Secession, from Otto Wagner to Hoffman, the German Jugendstil and Deutscher Werkbund, with Peter Behrens, and were also at the origin of the "civilizational» sign under which the Modern Movement was founded. In the same way, they stand at the valuing of the purism of form, as in the case of pictorial experiences present in the painting of Le Corbusier and Amédée Ozenfant in the 1920s, and as under the myth of nature, revealing the transcendentality and the mysticism of the various so-called "organic" discourses, based on the poetic reflection of Frank Lloyd Wrigth, under the influence of Walt Whitman pantheism, and also in the theosophical doctrine of Rudolph Steiner (Argan, 1997).

It is possible to conceive the idea that neoplatonism at the beginning of the 20th century synthesizes aesthetics apparently antagonistic, from romanticism and medieval idealism to the values of classicism, through principles with hermetic characteristics. It is through the myth of ancient lost traditions that these values are going to create several avant-garde movements in the field of arts and architecture, which sought to bring together the wills for change that met the will of regeneration of mankind through the recovery of a mythical legacy «to be rescued». This search will have been made, at times, through expressionist symbolism, through «silent laws» that rule the universe, of an hermetic and initiatic nature, understood as constant properties of these processes of ontological requalification (Argan, 1997).

This requalification breaks with the notion of historicist past and reconnects with the immutability of universal archetypes, in what Pythagoreans and initiatic societies called "Tradition". The term is understood not as "traditionalism" of a "historicist" or "conservative" nature, but as a rediscovery of Humanity's timeless values, "reintegrated" in its cosmic dimension, in short, initiatic (Freitas, 1990).

In this way of seeking reunification with the knowledge of the past, Orphism seems to have constituted one of the important regenerating currents of classic-hermetic origin within cubism itself (Galvão, 2003). In this case, the geometric-symbolic of the Greek myth would have served as a basis for the conception of a new abstract plastic order, which, according to some authors, would later enthrone in Neo-Pythagorean revival (Ghyka, 1978; Cleyet-Michaud, 1973) through the adoption of "Divine Geometry", referring specifically to the work of Luca Paccioli di Borgo, The Divine Proportion, and the Golden Number, mostly published since 1927 through works by Mathila Ghyka (Ghyka, 1978).

This other aspect of the modern imaginary can serve to explain its specificity as a nationalist or regionalist phenomenon, constituting itself as another link with its romantic past, surviving, in this case, through a double regionalism: that of classical heritage as a universal language and that of the 
rationality of the rustic heritage, of a spontaneous and rational architecture, "like the volume-forms proposed by cubism, as by purism or through a symbolic interpretation." (Galvão, 2003).

We must not forget that, in 1923, when Le Corbusier wrote that "Architecture is the wise, correct and magnificent game of volumes arranged under the light " (Le Corbusier, 1923), he took into account timeless values that should've been recovered for the poetic value of modernity, in a clear allusion to classicism and Mediterranean purism that marked him deeply and about which he left testimony in his travel notebooks to the East in 1911 (Le Corbusier, 2002).

In 1929 the Cercle et Carré movement emerges in Paris, founded by painter Joaquin Torres Garcia and art critic Michel Seuphor. In view of the omnipresence of surrealism, they brought together abstract-constructivist artists, the ideas of De Stil and the Bauhaus. Integrating Le Corbusier, Walter Gropius, Wassily Kandinsky, Piet Mondrian, Fernand Léger, Hans Arp and Georges Vantongerloo, would exhibit and publish in the following year at Galerie 23, in Paris, a homonymous magazine, where they disseminated and encouraged the development of abstract art, and in particular in its mystical aspect (Seuphor, M. \& Juin, H., 1977).

Subsequently absorbed by the publication Abstraction-Création, founded in 1933, it was particularly important in that it brought together artists and architects in the post-cubist period to the revaluation of the abstract cause, in this case through its symbolic and metaphysical valorization, resuming the Pythagorean-Platonic principles in the context of the scope of abstract values in modern society. In the same way, the need for the "modern man" to reconnect with his old traditions, was the founding principle of Constructivist Doctrine, by Torres Garcia, by "exporting», later, from Catalonia and Paris, the European vanguard into South America (TorresGarcia, 1969).

Consequently, these conjunctures allow us to consider that between "rational formalism" and the "Mediterranean 19th century" it is possible to glimpse at some aspects as common, albeit from different perspectives, such as classicism in its neoplatonic and neopitagoric form. Likewise, some authors also refer an attempt of modern synthesis among the most abstract aspects of classical values and the metaphysical discourse of 19th Mediterraneanism, as proved Margherita Sarfatti in 1924, as well as, more recently, William Curtis, on the modern concern with the geometric essentiality of classicism as a phenomena of renewal of the 19th century eclectic aspect (Curtis, 1996).

In this context, Mediterraneanism seems to be a key trend of the 20th century when it unites people and culture with the roots of the past and with a desire for the norm, through the symbolic path where the cube coincides with the typology of roof terrace houses.

As Eugénio d'Ors stated, in the beginning of the 20th century, "that the convenient orientation could not disconnect from tradition and that tradition was Mediterranean" (Bohigas, 2003), it is on this tradition that it seems to have been built an interpretation of modernity in southern Mediterranean countries. Outside the positivist realm which seems to have taken shape in the technical-functionalist models of the most northern regions, other possible interpretations to modernity, with the values of the Mediterranean cultural legacy would be too important to dissolve in the modern international aesthetic, having been recovered through the purism of the "lands of the south".

Hence the question of the importance of "Tradition" as a repository of supra-historical values, in addition to the popular legacy of ancient memory. In this case, it is not about the mimicry of styles, but the transmission of values and archetypal modes, namely of artistic and architectural conception, through a hidden thought that emerged from the depth, and becoming conscious, was inevitably symbolic. 
In short, the clarification of the complex genesis of European modernity at the beginning of the 20th century can be understood through its less explicit and paradoxical aspects, and the approach to its construction must be seen in the light of these same paradoxes, characteristic of the "Machine Age". Some searches for regeneration with the past seem to explain certain aesthetic and ideological options of artistic vanguards and architectural proposals. This would have occurred with the search for laws and archetypes that could lead to the legitimation of abstract models that could generate new responses to modernity in its various cultural aspects, in addition to the rationalist/functionalist model of international nature. The question of «Tradition» encompasses the cultural phenomenon of European roots, but also regional and ethnic phenomena, as in the case of classicism and its popular and Mediterranean aspect, as well as in the less explicit aspects, of hermetic root, that seem to have been regenerated through some artistic and architectural vanguards born from the metaphysics of the early 20th century.

The search for a new order would have been carried out under the eliadian myth of the "Eternal Return" (Eliade, 1969), in the search for an "other" universality based on the immutability archetypes and the transcendent capacity of symbols. Even though an infinity of values have crossed into this complex dialogue that the 20th century established with the romantic past, and in addition to the issues of integration, or not, of other currents within the modern paradigm, it is worth mentioning the rupture of the avant-garde, explicitly in confrontation with 19th century academic legacies. Conversely, lies an implicit continuity that these avant-gardes sought to establish, experiencing the regeneration of absolute and timeless values of knowledge linked to the distant past.

It is based on these less explicit and apparently paradoxical outlines of the "various interpretations of modernity" that the understanding of the Mediterranean case, in its cultural, regional and vernacular condition, becomes possible. In the same way, they seem to pave the way for other readings, which the simple binomial academism/modernism sometimes hardly clarifies.

\section{Part Two}

In the second part we start by taking into account, trough some examples, the overall values of Mediterranean architecture and how can they be perceived as common fundamentals, or archetypes, from tradition to modernity, as a whole richness of diversities, plurality and contrasts of typologies, regions, cultures (north/south; east/west).

First, can we perceive the existence of overall values in the Mediterranean architecture? Does its identity come from common fundamentals or from a richness of contrasts and diversities? If we postulate a presence of common fundamentals, we can also recall that some archetypes manifest themselves from tradition to modernity and into a whole richness of pluralities and contrasts, regarding building and urban typologies, regions and cultures, from north to south and from east to west.

On the other hand, we can also postulate that the homogeneity of the Mediterranean urban traditional landscape depends on the scale at which we are analyzing some particular issue, either at an urban scale or just exploring the variations of some particular housing typology.

As we have seen in the first part, this issue is also related to the adaptation of modernity in the Mediterranean, the genesis of XXst century modernism and its own globalistic paradigm and adaptation. Let us not forget that the "rational south" contemporary definition of "meridional architecture" can somehow genetically be related to the famous definition of architecture by Le Corbusier, as "the masterly, correct and magnificent play of volumes brought together in light", which can be considered, at its origin, a Mediterranean definition of Architecture or, at least, a very "southern" aesthetical approach by the Swiss master - mostly influenced, at start, by his famous "Voyages en Orient" in the late 1910's, under the influence of Cézanne's modern theory ("Il faut 
traiter la nature selon le cube, la sphère et le cône"), and continued with his own quest of purism, along with Amedée Ozenfant in the 1920's (Le Corbusier, 2011).

On a phenomenological approach, we can see that the Mediterranean is also a contrast between what Christian Norberg-Schulz has called, on one occasion, the classical landscape and, and on another, the cosmic landscape (Norberg-Schulz, 1980). By this categorization, we can recognize that Classical landscape defines mostly the northern side of Mediterranean (most meridional European territory) as the typical aesthetics of Provence and Toscania landscapes reflect and, on the southern side, the cosmic landscape of north Africa, the east Mediterranean, from Turkey to Israel, and southern Iberian Peninsula, where the images of old seaside villages of Algarve (الغرب, al-gharb, i.e. "the West"), the Baleares, or Sicily, can be, at first glance, mistaken for some urban settlements in Morocco or Tunisia. How could we forget that Alfama (ألف ماء, from alfa, i.e. "thousand", and maa, i.e. "water") - Lisbon's iconic district - is, at its origin - like Grenada and other southern cities - a very old medina?

If we take a look at several south Mediterranean cities, we can easily recognize resemblances in urban morphology and buildings typologies. Houses, neighborhoods, streets, pathways, squares and markets create a natural balance between the private areas - the "hidden" city of intimacy and mystery of most Mediterranean historical urban centers - and the public ones -, of social economic grandness, symbolism and monumental exposure, as the Athenian ancient Agora, the roman Forum, the venezian Piazza San Marco, the Renaissance's Piazza della Santíssima Annunziata in Florence, the Capitol in Rome, the Plaza Mayor in Madrid or the Neoclassical Praça do Comércio in Lisbon. This diversity creates a richness of fundamentals values that could not have had any meaning without it. Even some idiosyncratic or picturesque aspects participate to the embodiment of identity trough the introduction of variety.

One classical example of this phenomenon is Malaparte's House in Capri, a typical case-study on its own (Figure 1). The main difference between Adalberto Libera's version and Curzio Malaparte's final version is the globalistic modern functionalist proposal contrary to the final solution based on the local and on the clients program, circumstances, pragmatism, memory and poetry. This resulted in a most unique place and a symbolic statement that has built its mythical identity as an idiosyncratic case-study in the History of Modern Architecture. Paradoxically, one could almost say that if Libera's functionalistic proposal would have ever been built, it wouldn't have had the same charisma and poetry as the Malaparte's parti, like an Ortega y Gasset's metaphysical thought, in which man is himself and his circumstances (Ortega y Gasset, 2004). An aesthetical approach that could be regarded not so far from the early 1900's catalan's "noucentisme", as opposed to modernism, or, as we have established in the first part, late 1930's Torres Garcia's Constructivist theory, a redemption of modernity through what the painter-poet called "direct symbolism", as a reflection on classical tradition and timeless Mediterranean archetypes, which should form, according to the latter, "The tradition of the abstract man". In other words, we could say that the question of identity in the Mediterranean comes from the diversities and the cultural balances that feed its own kairos, between reality, imaginary and myth. 


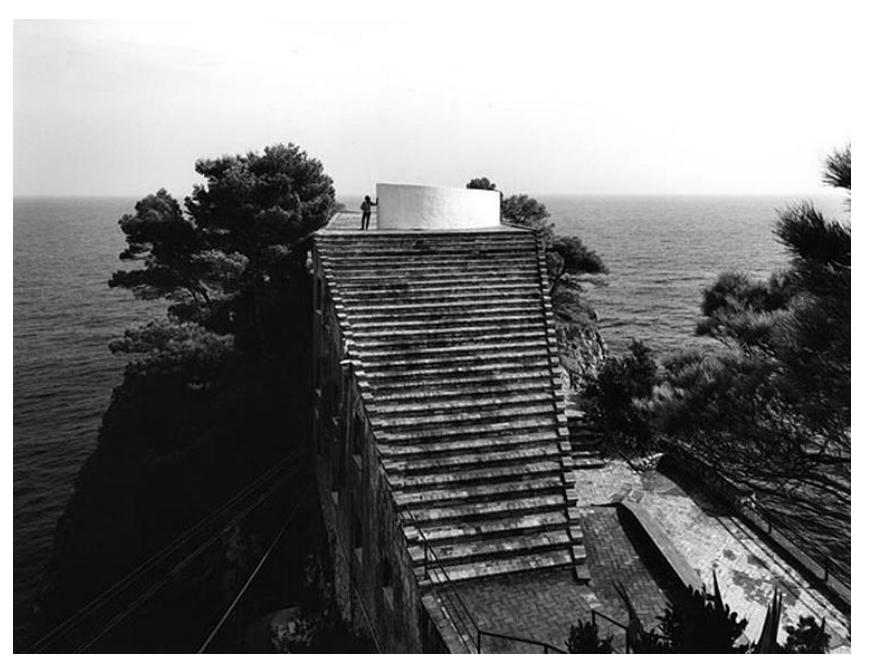

Figure 1 Adalberto Libera, Casa Curzio Malaparte, Capri, 1937-41 (Url 1).

On the other hand, common - and sometimes opposite - fundamentals create its own richness of contrasts and diversities. The contrast of cultures and civilizations (north/south; east/west) has always existed at the very heart of this great "inner sea". Either be its geographical, climatic, urban, typological, social or symbolic aspects, we believe that its own memory should be preserved in the globalization issues. Like Aldo Rossi (2001) and Françoise Choay (2007), one should remember that identity is build up on memory - and this applies not only to persons but also to buildings, places and cities.

If we agree on the existence of these fundamentals and diversities, how can we value them? This leads to us to our second question: which/how these fundamentals and diversities could/should be integrated or highlighted?

According to the analysis of Pierre Von Meiss regarding Hydra's urban landscape (Figure 2a, b), it is almost impossible to recognize the differences between two apparent identical images of the town. According to the author: "Hydra: two identical images? Almost, but not quite, because when you look better at the second one, you discover the insertion of very modern works: a) part of Alvaro Siza's ensemble at Évora (1977); b)+d) Le Corbusier's and Hans Scharoun Weisenhoff houses (1927); c) Adolf Loos Moller House (1927). Yet, everything is still quite harmonious - even maybe for the curator of the heritage center. This is due to the consistency of factors well beyond any attempt at imitation. There are good reasons to reconsider our protective regulations or develop another approach to the protection of sites." (Von Meiss, 2012). Besides the wise criticism and pedagogical approach in Von Meiss's lesson - let us not forget that this example is taken from a book addressed, firstly, to architectural students -, we can nevertheless point out that the author chooses carefully to insert modernist models in accordance with the "cubic white image" of some Mediterranean traditional typology, in an almost iconographic "mise-en-scène". 

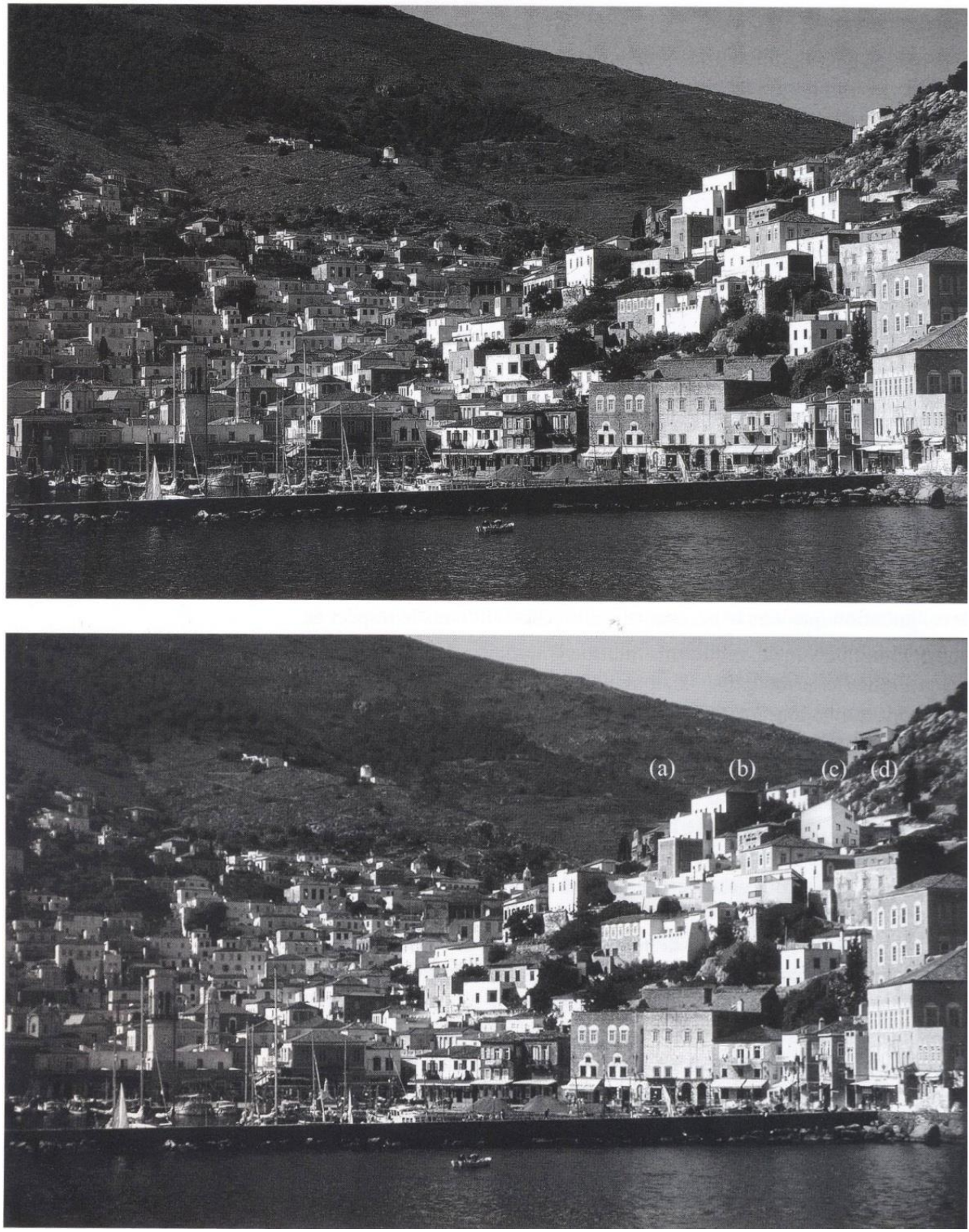

Figure 2a, b. a): Hydra's urban landscape; b): a photomontage with the inclusion of some modern architectural major works: a) part of Alvaro Siza's ensemble at Évora (1977); b)+d) Le Corbusier's and Hans Scharoun Weisenhoff houses (1927); c) Adolf Loos Moller House (1927). In Von MEISS, Pierre, De la forme au lieu+ de la techtonique, fig. 63, p. 54.

In opposition, it is rather obvious that the same analysis would be completely different if we had to choose, for instance, a Frank Lloyd Wrigth prairie house, Mies van der Rohe's Barcelona Pavillion, Le Corbusier's Villa Schodan, Alvar Aalto's Saynätsalo Center or even Eero Saarinen's JFK-TWA Terminal. So, we can conclude that there is some modernism that is adapted to the Mediterranean landscape because it is genetically related to the rational and southern approach of dwelling and man's relation of building its own cultural space. The modernistic examples in the image are accurate, not because of its functionalist principles, but because of their analogies with the local typology and urban morphology, where the almost prophetical quote of Le Corbusier blooms to the uttermost, as "the masterly, correct and magnificent play of volumes brought together in light" (Le Corbusier, 1923) comes full circle.

So, if we can identify and integrate fundamentals, what can we learn about diversity? If we observe Alvaro Siza's Malagueira in Portugal, we can see that diversity lies mainly on volumetric variations on the housing typologies and its blocks adaptation to topographical variation. 
Nevertheless, one can see that street typology and the overall urban design morphology is basically the same. Paths and ways are almost identical by repetition of type, so most habitants don't seem to have created a strong sense of identity with "their own" street. In some way, this may be due to the author's idea of spatial continuum, as a fragmented design process of urban growing continuum. Although, we should not forget the repetition on street typology and overall urban morphology and some absence of real structuring public squares - with the exception of some common "terroirs" -, public equipments, and therefore, a lack of psychological centeredness and social identity within the community's district.

Conversely, if we take a look at another classical example of Mediterranean design, like Hassan Fathy's New Gourma village in Egypt, we can see that the author created a urban form based on traditional housing, equipments, streets and squares typologies, adapting some basic models to the village morphology in order to create a diverse urban spatiality, avoiding repetition of models, and therefore creating a richness and strong locus identity throughout diversity (Fathy, 1970).

The lesson we can learn from these modern Mediterranean experiences is that repetition "kills" identity, and one should understand that models should adapt to the local. If we take a look on the actual adaptability of some late 1950's structuralistic experiences in urban design and social housing in north Africa by some of Team X members and followers, it is impossible not to feel that the globalist theories have failed its integration because of its lack of adaptation to the economic, social, cultural contexts and its implications in the territory and specificities (Figure 3 and 4). We believe that case-studies like these should be understood - in their strengths and weaknesses - in order to overcome globalist and local issues.

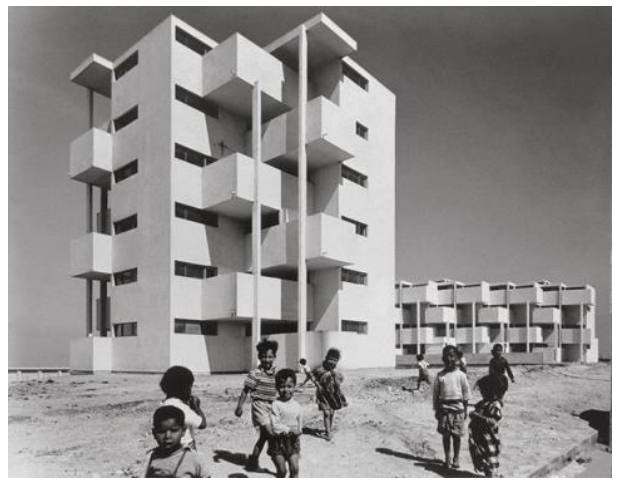

Figure 3 André Studer \& Jean Hentsch, Sidi Othman Apartment Buildings, Casablanca (1955), (Url 2).

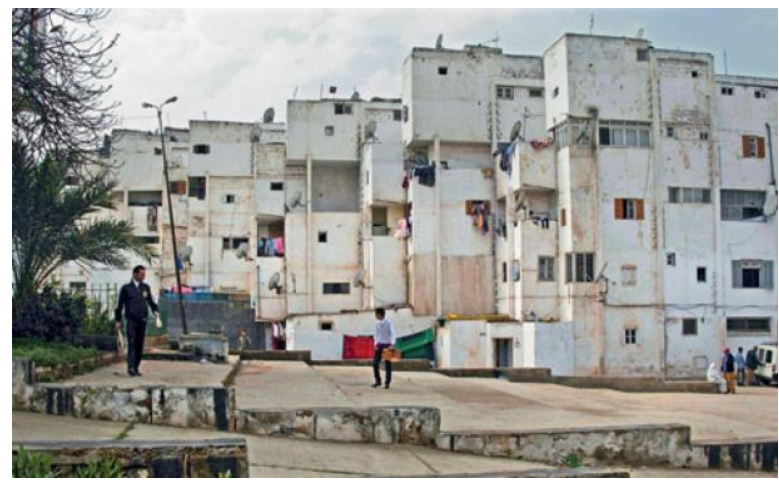

Figure 4 André Studer \& Jean Hentsch, Sidi Othman Apartment Buildings, Casablanca, in 2008, (Url 3).

This leads us to our last question: can these fundamentals and diversities become "operative" in architectural or urban design offices? How do they respond to the globalization phenomena and the possibility of real sustainable achievements?

"Be aware that $99 \%$ of your future design projects will be on common matter", said Professor Von Meiss addressing to students (Graduation speech at Universidade Moderna de Setúbal, 2001). This - somewhat "provocative" statement - also means that even if students can learn a lot from the major architectural "masterpieces" (either from past or present), one should not forget that these examples represent only about $1 \%$ of buildings in reality, and that students should be taught to understand localness, at the same time they study major historical and theoretical aspects and global movements phenomena. In other words, one should study the typological but should not forget the topological aspects in the design process. This also means that without a proper topological understanding of the site there is no "local" or "southern/Mediterranean" approaches to design matters and consequents skills and sustainable operativeness. 
In conclusion, in order to synthesize some answers to our questions: 1) Does the identity of Mediterranean architecture come from common fundamentals or from a richness of contrasts and diversities? 2) Can these fundamentals and diversities become "operative" in architectural/urban design? And how do they respond to the globalization phenomena and the possibility of real sustainable achievements? We could say, firstly, that the identity of the Mediterranean comes from its own diversity and cultural balance. Common - and sometimes opposite - fundamentals create its own richness of contrasts and diversities. This contrast of cultures and civilizations (north/south; east/west) has always existed at the very heart of Mediterranean. Either in its geographical, climatic, urban, typological, social or symbolic aspects, its memory should be preserved in the globalization issues, as without memory there is no possibility of identity of space, places or people. However, despite the evidence, this idea raises some other questions, such as: a) the negation of the local implies the oblivion of its identity; b) the typological exercise should be considered within a topological approach, in order to contextualize architectural programs and urban strategies and to ultimately create new meanings; c) conversely, at a local level, Mediterranean heterotopias can have their own multi-layered identity, provided that one can recognize spatial, psychological and cultural perception beyond the sum of its parts. Furthermore, they can respond to the globalization phenomena if the consciousness of diversity is preserved, understanding complexity and heterotopia over dystopia, and typology through topology.

\section{Conclusion}

In conclusion, in order to synthesize some answers to our questions: 1) Does the identity of Mediterranean architecture come from common fundamentals or from a richness of contrasts and diversities? 2) Can these fundamentals and diversities become "operative" in architectural/urban design? And how do they respond to the globalization phenomena and the possibility of real sustainable achievements? We could say, firstly, that the identity of the Mediterranean comes from its own diversity and cultural balance. Common - and sometimes opposite - fundamentals create its own richness of contrasts and diversities. This contrast of cultures and civilizations (north/south; east/west) has always existed at the very heart of Mediterranean. Either in its geographical, climatic, urban, typological, social or symbolic aspects, its memory should be preserved in the globalization issues, as without memory there is no possibility of identity of space, places or people. However, despite the evidence, this idea raises some other questions, such as: a) the negation of the local implies the oblivion of its identity; b) the typological exercise should be considered within a topological approach, in order to contextualize architectural programs and urban strategies and to ultimately create new meanings; c) conversely, at a local level, Mediterranean heterotopias can have their own multi-layered identity, provided that one can recognize spatial, psychological and cultural perception beyond the sum of its parts. Furthermore, they can respond to the globalization phenomena if the consciousness of diversity is preserved, understanding complexity and heterotopia over dystopia, and typology through topology.

\section{References}

Argan, G. C., (1997), El pasado en el presente: el revival en las artes plásticas, la arquitectura, el cine y el teatro, Gustavo Gilli, Barcelona.

Bohigas, O. (1996), História de la Cultura Catalana, Vol. VII, Ed. 62, Barcelona, 202.

Choay, F. (2007), A Regra e o Modelo, Ed. Caleidoscópio, Lisboa.

Corbusier (Le), (1923), Vers une architecture, Crès, Paris, 16.

Corbusier (Le), (2002), Voyage d'Orient - carnets, (1911), Electa Architecture/ Fondation Le Corbusier, Paris.

Curtis, W. (1996), Modern Architecture since 1900, Ed. Phaidon, Londres, 360.

Eliade, M. (1969), Le mythe de l'éternel retour. Archétypes et répétition, Paris, Gallimard, col. Idées.

Fathy, H. (1970). Construire avec le peuple, Sindbad.

Francastel, P. (1963), Arte e Técnica nos séculos XIX e XX, col. Vida e Cultura, Livros do Brasil, Lisbon. 
Frampton, K. (1997), História crítica da arquitectura moderna, Martins Fontes, São Paulo, 194-195.

Freitas, L. (1990), Pintar o Sete: ensaios sobre Almada Negreiros, o Pitagorismo e a Geometria Sagrada, Colecção Arte e Artistas, Imprensa Nacional - Casa da Moeda, Lisboa, 82-83.

Galvão, A. (2003), O Caminho da Modernidade: A travessia portuguesa, ou o caso da obra de Jorge Segurado como um exemplo de complexidade e contradição na arquitectura (1920-1940), Universidade Lusíada, 34.

Ghyka, M. (1978), El Numero de Oro - ritos y ritmos pitagóricos en el desarrolo de la civilización occidental, Editorial Poseidon, Barcelona.

Giedion, S. (2003), Space, Time \& Architecture: the Growth of a New Tradition, Harvard University Press.

Cleyet-Michaud, M. (1973), Le Nombre d'Or, Presses Universitaires de France.

Seuphor, M. \& Juin, H. (1977), Cercle et carré: 1930, Ed. Jean-Michel Place, Paris.

Ortega y Gasset, J., 2004. Meditaciones del Quijote, Obras Completas, Vol. I. Ed. Taurus, Fundación José Ortega y Gasset, Madrid.

Rossi, A (2001), A Arquitectura da Cidade, Ed. Cosmos, Lisbon

Tafuri, M. (1988) Teorias e História da Arquitectura, Presença, Lisbon, 38-39.

Torres-García, J. (1969), La tradición del hombre abstracto (Doctrina constructivista), Ed. Comisión de Homenajes a Torres García/Ministerio de Educación y Cultura de la República Oriental del Uruguay, Montevideo.

Von Meiss, Pierre (2012), De la forme au lieu+ de la techtonique, Presses polytechniques et universitaires romandes - PPUR, 54 - fig. 63.

URL 1 https://www.arquiscopio.com/pensamiento/wpcontent/uploads/2013/03/130324_Basilico_Libera_C asaMalaparte82s.jpg accessed 10 February 2021 at $16 \mathrm{H} 30$.

URL 2 Taken from https://www.pinterest.pt/pin/492018328014925047/ accessed 10 February 2021 at $16 \mathrm{H} 45$.

URL 3 Taken from https://www.wallpaper.com/architecture/book-colonial-modern\#0_pic_2 accessed 10 February 2021 at $16 \mathrm{H} 50$.

\section{Resume}

Hugo Nazareth Fernandes is a research member of Arch. ID research center and Assistant Professor in the Department of Architecture and Urbanism at ULHT - Lusófona University of Lisbon. 2nd PRIZE ICAR CORA2011 / International Council for Architectural Research - ICAR-CORA PRIZE 2011 for Best Doctoral Thesis. 